\title{
SPATIAL DIVERSITY OF INFRASTRUCTURE AND ITS IMPACT ON THE DEVELOPMENT PROCESS OF RURAL COMMUNES IN EASTERN POLAND IN 2009-2018
}

\author{
Paweł Dziekański'
}

\begin{abstract}
Local government units are developing in an increasingly complex environment that is a place of concentration of economic activity and is a creator of local and regional development. Their activities target all types of resources, i.e., financial, human, material and information. The aim of the article is to rating the diversity of infrastructure of rural communes of Eastern Poland in relation to development. The measurements were carried out using a synthetic measure in a system of 484 communes. Data from the Local Data Bank for 2009-2018 was used as the source material. Development is a general process, multi-dimensional process, covering economic, social, environmental, political and cultural aspects. Regions with a high level of infrastructure development are areas recognized by investors and residents as attractive places for doing business and living. The level of infrastructure development in a given local system in terms of its structure, location, quality and accessibility has a very strong impact on its development. In 2018, the infrastructure measure ranged from 0.23 (best unit) to 0.91 (the weakest unit), and from 0.35 to 0.91 in 2009. In 2018, the measure of development ranged from 0.43 to 0.82 , while it ranged from 0.52 to 0.84 in 2009. This indicates a similar range of unit diversity and similar actions undertaken in the economy. Units in the aspect of the measure of development and infrastructure differed the least in the aspect of entrepreneurship, demography and labor market as well as the financial situation, and the most in the aspect of infrastructure and development. The level of infrastructure of Eastern Polish rural communes was shaped primarily by the development process and financial situation but also by the number of people costing from libraries, sewage system and water supply as well as housing resources.
\end{abstract}

Key words: infrastructure, development, synthetic measure, rural communes.

Jel Classification: H54, J58, O10, R11

\section{Introduction}

Local government units are developing in an increasingly complex environment, which is a place of concentration of economic activity and is a creator of local and regional development. Their activities target at all types of resources, i.e., financial, human, material and information (Dworakowska, 2013). Factors differentiating the manner of performing individual tasks are the financial capabilities of the commune and the actual needs of residents and business entities operating on its territory. The endogenous potential of the individual is important for development. It causes diversity in the level of socio-economic development of local government units (Heffner, 2002).

Socio-economic development is a set of changes aimed at increasing the satisfaction of the collective and individual needs of local residents (Rosner,
Stanny, 2014). It is an ambiguous and complex concept, it results from the multitude of goals it is to serve and the variety of activities that shape it (Wojtasiewicz, 1996).

Infrastructure plays a particularly important role in regional development processes. Its importance is primarily due to the fact that the level of land use with infrastructure elements is one of the basic conditions for economic development. Infrastructure is a decisive element in the standard of living of residents and makes them more or less attractive to potential residents and investors or the location of economic activity (Dolata, 2014). Appropriate equipment with technical and social infrastructure is a prerequisite for economic activation. Development requires greater saturation of areas with infrastructure. The level of infrastructure is directly related to the development of entrepreneurship. The right infrastructure reduces the cost of the project,

Corresponding author:

${ }^{1}$ Jan Kochanowski University in Kielce, Poland.

E-mail: pdziekan@interia.eu

ORCID: https://orcid.org/0000-0003-4065-0043

ResearcherID: H-4658-2016 
determines its effectiveness and the ability to meet the requirements of residents or tourists (Pięcek, 2002).

\section{Materials and methods}

The aim of the article is to rating the diversity of infrastructure of rural communes of Eastern Poland in relation to development. The measurements were carried out using a synthetic measure in a system of 484 communes. Data from the Local Data Bank for 2009-2018 was used as the source material.

In the first stage of research, variables were selected for analysis. It resulted from substantive and statistical premises and data availability (Table 1). After selecting the variable, the nature of each variable was examined, i.e., it was determined whether the variable was a stimulant or a destimulant. From the set of variables, those characterized by low variability (according to the coefficient of variation, the threshold value was adopted at the level of 0.10 ) and high correlation of variables (according to the inverted matrix method) were removed (Malina, 2004).

The stimulant and destimulant sets were determined and presented in the form of an observation matrix $x_{i j}$ :

$$
x_{i j}=\left[x_{11} x_{12} \ldots x_{1 m} x_{21} x_{22} \ldots x_{2 m} \ldots \ldots \ldots \ldots x_{n 1} x_{n 2} \ldots x_{n m}\right]
$$

where $x_{i j}$ denotes the values of the $\mathrm{j}$-th feature for the i-th object $(i=1,2, \ldots, n ; j=1,2, \ldots, m)$.

Variable destimulants were transformed into stimulants according to the formula (Kolenda, 2003):

$$
x_{i j}=\frac{1}{x_{i j}}
$$

In the next stage, selected variables were subjected to the procedure of zeroed unitarisation using the following formula:

$$
z_{i j}=\frac{x_{i j}-\min _{i} x_{i j}}{\max _{i} x_{i j}-\min _{i} x_{i j}} \text {, when } x_{i} \in S
$$

where: $S$ is stimulant, $D$ is destimulant; $i=1,2 \ldots n$; $j=1,2 \ldots n$, xij means the value of the $j$-th feature for the examined unit, max is the maximum value of the $\mathrm{j}$-th feature, min is the minimum value of the $\mathrm{j}$ - feature (Wysocki, Lira, 2005). As a result of the unitarisation process, the matrix of property values was obtained $z_{i j}$ :

$$
z_{i j}=\left[z_{11} z_{12} \ldots z_{1 m} z_{21} z_{22} \ldots z_{2 m} \ldots \ldots \ldots \ldots z_{n 1} z_{n 2} \ldots z_{n m}\right]
$$

where zij is the unified value of xij.

The synthetic measure was calculated according to the method based on distance in real space with the Euclidean metric according to the formula:

$$
O E_{i t}=\sqrt{\frac{1}{p} \sum_{j=1}^{p}\left(1-z_{i j t}\right)^{2}}
$$

when $\mathrm{i}=1,2 \ldots \mathrm{N} ; \mathrm{j}=1,2 \ldots, \mathrm{p}$ ( $\mathrm{N}$ is the number of objects (powiats), ap is the number of features); zij means the value of the $j$-th feature for the given unit, max - the maximum value of the $j$-th feature, min is the minimum value of the $\mathrm{j}$-th feature (Wysocki, 1996). When the indicator value is equal to 0 , the given

\begin{tabular}{|c|c|c|}
\hline Infrastructural potential & Unit & $\mathrm{S} / \mathrm{D}$ \\
\hline Population per 1 library (person) & person & S \\
\hline Population using the sewage network & person & $S$ \\
\hline Population using the water supply network (person) & person & $S$ \\
\hline Housing stock per 1000 inhabitants & - & $S$ \\
\hline \multicolumn{3}{|l|}{ Development potential of the region } \\
\hline Change in population per 1000 inhabitants & person & $S$ \\
\hline Population Growth per 1000 inhabitants & person & $S$ \\
\hline Migration rate per 1000 inhabitants & person & $S$ \\
\hline Unemployed persons registered by sex in communes / person & person & $\mathrm{D}$ \\
\hline Employed persons in communes by sex / person & person & S \\
\hline Demographic dependency ratio for the elderly & - & $\mathrm{D}$ \\
\hline Housing stock per 1000 inhabitants & person & S \\
\hline Population per 1 library (person) & person & $S$ \\
\hline Population using the sewage network & person & $S$ \\
\hline Population using the water supply network (person) & person & $S$ \\
\hline Entities entered into REGON register & person & S \\
\hline Self-employed persons & person & $S$ \\
\hline Foundations, associations and social organizations & person & $S$ \\
\hline Own income / total income & $\%$ & $S$ \\
\hline Investment expenses / total expenses & $\%$ & $S$ \\
\hline
\end{tabular}
commune is characterized by the maximum value of each of the examined variables. The higher the value of

Table 1

List of variables describing the infrastructure situation and development potential

as- stimulant; $\mathrm{d}$ - destimulant

Source: own study based on the availability of data at the Central Statistical Office of Poland 
this indicator, the worse the situation of the commune (Tokarski, 2005).

In the last stage of analyses, in order to interpret the obtained measures, the division into quartile groups was used, where the size of the indicator in the first group means a better unit and in subsequent groups it means weaker units. The mutual compliance of the obtained results was also verified based on the correlation coefficient and the synthetic measure scatter chart was presented (Dziekański, Wyszkowski, 2018).

\section{Development vs infrastructure level - selected issues}

The commune is a self-government community of inhabitants living in a given territory. Their main goal is to provide residents with the highest standard of living. The quality of life of the inhabitants depends on the public services provided by the commune (Milczarek, 1999). Infrastructure, financial and social capital, etc. are important for the development of municipalities' potential. An important issue for the functioning of municipalities is the diagnosis and assessment of resources, followed by the implementation of measures to maintain a high level of development or change its unfavorable direction in time (Heffner, 2002). Municipalities do not develop evenly. The reasons for this can be seen in access to factors of production, land and capital. The potential of people is also important. The development is not only the result of the administration, but also simultaneous activity in a specific area of enterprises, as well as citizens. Development is the entirety of the socio-economic changes taking place in a given territory (Krajowy Raport o Rozwoju Społecznym, Polska 2012, Rozwój regionalny i lokalny). A. Sztando emphasizes that local development is a process of multidimensional changes in the numerous set of various elements that make up modern society, the economy and the environment, as well as even more numerous connections between these elements (Sztando, 2013).

Development is associated with two priorities: optimal use of endogenous resources and building social, economic and territorial cohesion (Capello, Nijkamp, 2011). It occurs more dynamically in more developed areas, characterized by favorable geographical location, developed infrastructure, favorable conditions for creating and accumulating innovations, and values of the natural and cultural environment (Karwińska, 2006). At the same time, this situation contributes to further marginalization of problem areas.

Determinants identifying development include relations between the environment and the commune, endogenous resources, geographical location, infrastructure resources, human capital, etc. Internal factors include local resources. They are made up of, among others, property resources, natural environment resources and demographic resources, infrastructure, financial resources. They should not be seen as individual isolated variables. The resources owned are the basis for operation and a condition for the entity to carry out statutory tasks (Prus, Sadowski, 2012). In the case of external factors, first of all, the state policy is analyzed, with particular emphasis on social issues, the quality of life of residents, and the close and distant environment (Waśniewsk, 2015).

Financial resources are an element necessary for the effective implementation of the units' objectives in terms of current or development tasks. There is feedback between socioeconomic and financial variables (Dennis, 2004). Finances allow for a comprehensive assessment of the operation of a local government unit and its development opportunities. J.W. Douglas and R.K. Gaddie relate the financial situation to the possibility of timely fulfillment of financial obligations and ensuring continuity in the provision of services (Douglas, Gaddie, 2002).

Natural conditions (natural environment) are a primary and at the same time passive growth factor. The very fact of the existence of favorable natural conditions in a given area does not prejudge the structure of its economy or the level of its development. The degree and directions of use of natural resources depend on human activities. Natural resources include: natural resources, natural forces and environmental qualities that determine the quality of human life (Dennis, 2004).

Equipping a given area with social and economic infrastructure facilities is one of the factors and determinants of investment attractiveness and development. It affects the quality of life of residents by meeting the collective needs of the local community and business entities. It contributes to the development of existing companies and is an incentive for external investment (Busłowska, 2011). According to K. Kuciński (Busłowska, 2011), infrastructure is a set of devices, facilities and institutions that support and connect spatial systems into one unit.

B. Pięcek emphasizes that infrastructure is a necessary condition, but not a factor in the development of economic activity (Pięcek, 2002). According to A. Gałązka, wherever socio-economic transformations take place in ordinary, average environmental conditions, maintaining development processes requires infrastructural support. The initiation of positive socio-economic transformations in areas with weak development factors is even more dependent on the availability of municipal infrastructure (Gałązka, 2003).

In the process of development, infrastructure is one of the elements of creating a business, determining its scope, structure and spatial distribution. The level of infrastructure may determine the opportunities or barriers to its further development. Infrastructure as a factor activating socio-economic progress is also one of the important determinants of the living conditions 
of the population. This is particularly important in the conditions of scarcity and inheritance of a regionally diverse infrastructure system. This, in turn, leads to a deepening of the competitive advantage of areas more economically developed and characterized by relatively high development dynamics so far. In Poland, this problem is particularly evident in the so-called rural problem areas, where significant shortages in equipment with technical infrastructure can significantly reduce the future development prospects (Rosner, 2000).

\section{Development and the level of infrastructure of rural communes in Eastern Poland}

In 2018, the infrastructure measure ranged from 0.23 (Białowieża, Podlasie, the best units, Group A) to 0.91 (Dynów, Podkarpackie, the weakest unit, Group D, Figure 1), and from 0.35 (Białowieża, Podlasie) to 0.91 (Dynów, Podkarpackie) in 2009. The range of values adopted by the infrastructure measure was slightly higher in 2018 (range 0.68) than in 2009 (range 0.56, table 3). In 2018, Białowieża, Radków, Terespol, Łukta, Lutowiska, and Rejowiec Fabryczny found themselves high.
In 2018, the measure of development ranged from 0.43 (Stawiguda, Warmińsko-Mazurskie, best units, Group A) to 0.82 (Nozdrzec, Podkarpackie, the weakest unit, Group D, Figure 2), and from 0.52 (Stawiguda, Warmińsko-Mazurskie Voivodeship) to 0.84 (Miączyn, Lubelskie) in 2009. The range of values adopted by the measure of development was slightly higher in 2018 (range 0.39) than in 2009 (range 0.32, Table 3). In 2018, they were high in the development aspect: Stawiguda, Lutowiska, Juchnowiec Kościelny, Puchaczów, Sitkówka-Nowiny.

By far the highest level of infrastructure characterized in 2018, according to the synthetic measure, were the rural communes of the Lubelskie Voivodeship ( $40 ; 24.24 \%$ of the communes of the voivodeship), Podlasie $(28 ; 35.89 \%)$ and Warmińsko-Mazurskie (22; 32.83\%), and according to the measures of Lublin (37; 22.42\%), Podkarpackie (39; 36.11), Świętokrzyskie $(28 ; 42.42 \%)$ and Warmińsko-Mazurskie Voivodeship (28; 41.79\%) (Table 2).

Figure 3 shows the increase in the diversity of rural communes by infrastructure measure and a slight decrease by development measure in 2018 compared to 2009. Outliers in this respect were Dynów, Brzyska,
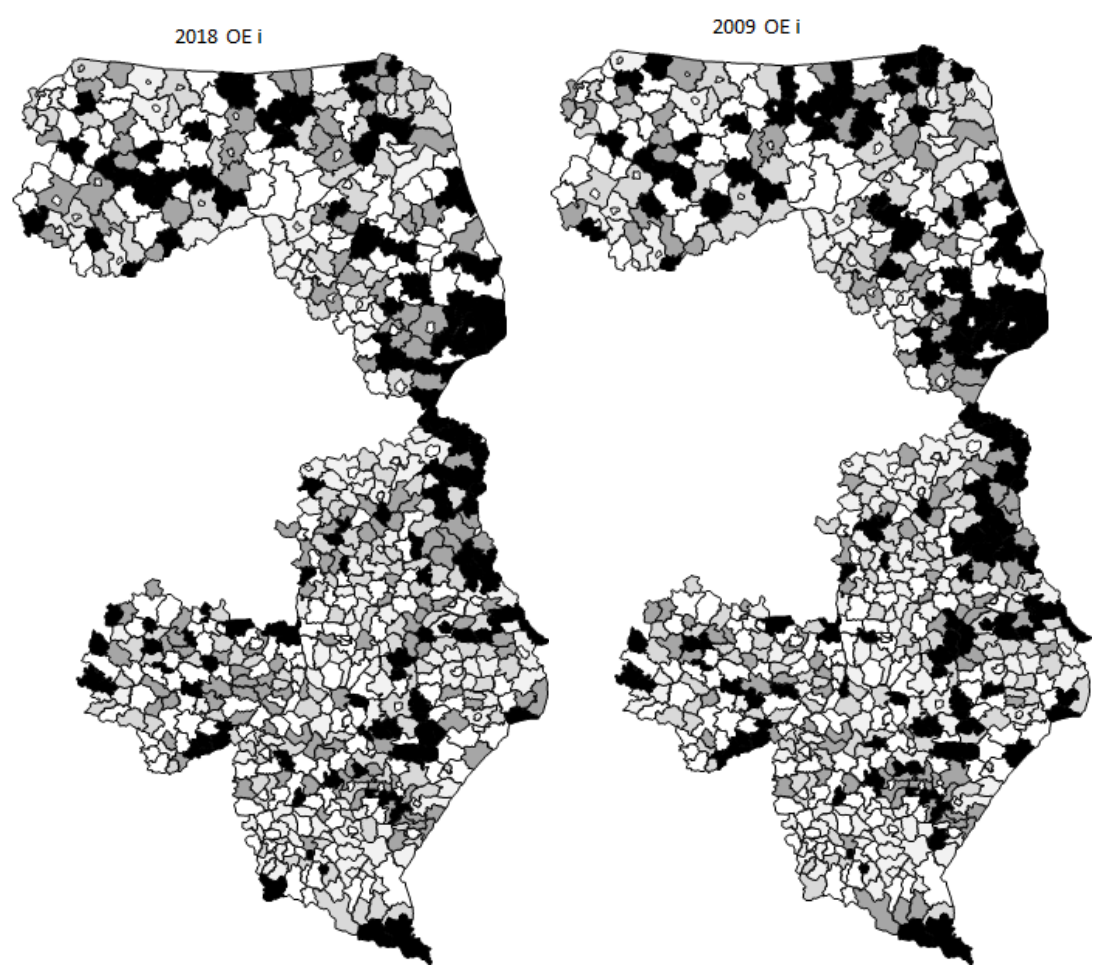

Gr A

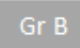

Gr C

Gr D

Figure 1. Groups of quartile measures of synthetic infrastructure (OE) of rural communes of Eastern Poland voivodeships in 2009 and 2018

The first, second and third quartiles were used as the thresholds for the groups; black craft top; white color is the urban and urban-rural commune not covered by the study.

Source: own development based on the data from the Local Data Bank of Statistics Poland and Central Statistical Office 
Vol. 6, No. 5, 2020

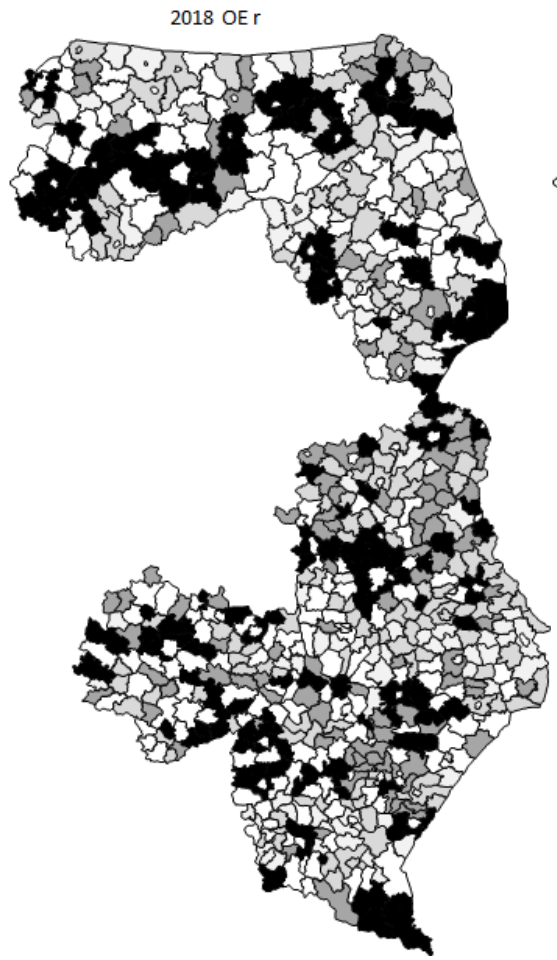

Gr A

Gr B

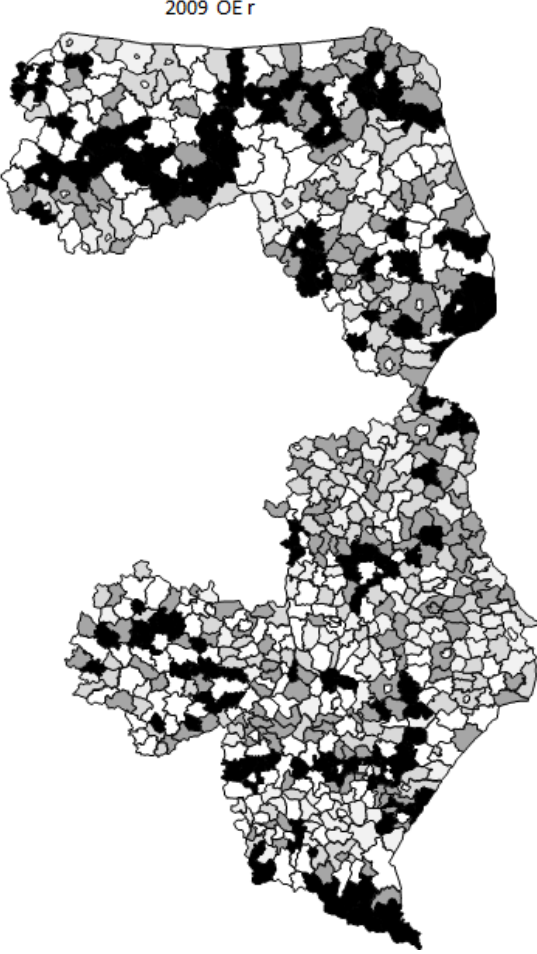

GrC

Gr D

Figure 2. Quartile groups measure of synthetic development (OE) of rural communes in Eastern Poland voivodeships in 2009 and 2018

The first, second and third quartiles were used as the thresholds for the groups; black craft top; white color is the urban and urban-rural commune not covered by the study.

Source: own development based on the data from the Local Data Bank of Statistics Poland and Central Statistical Office

Table 2

Groups by commune belonging to the Eastern Poland voivodeship

by synthetic infrastructure and development measure in 2009 and 2018

\begin{tabular}{|l|c|c|c|c|c|c|c|c|c|}
\hline \multirow{2}{*}{ Infrastructure measure } & \multicolumn{4}{c|}{2009} & \multicolumn{4}{c|}{2018} \\
\cline { 2 - 12 } & & A & B & C & D & A & B & C & D \\
\hline Lubelskie & 165 & 47 & 26 & 43 & 49 & 40 & 38 & 41 & 46 \\
\hline Podkarpackie & 108 & 21 & 25 & 22 & 40 & 18 & 28 & 27 & 35 \\
\hline Podlaskie & 78 & 32 & 20 & 17 & 9 & 28 & 22 & 13 & 15 \\
\hline Świętokrzyskie & 66 & 16 & 18 & 22 & 10 & 18 & 25 & 17 & 6 \\
\hline Warmińsko-mazurskie & 67 & 24 & 18 & 17 & 8 & 22 & 20 & 16 & 9 \\
\hline Number of units & 484 & 140 & 107 & 121 & 116 & 126 & 133 & 114 & 111 \\
\hline Average & 0.57 & 0.65 & 0.70 & 0.74 & 0.49 & 0.58 & 0.65 & 0.73 \\
\hline Range & \multicolumn{7}{|c|}{0.17} \\
\hline
\end{tabular}

\begin{tabular}{|l|c|c|c|c|c|c|c|c|c|}
\hline \multicolumn{2}{|c|}{ Measure of development } & \multicolumn{9}{c|}{2009} & \multicolumn{4}{c|}{2018} \\
\cline { 2 - 12 } & & A & B & C & D & A & B & C & D \\
\hline Lubelskie & 165 & 19 & 53 & 46 & 47 & 37 & 38 & 60 & 30 \\
\hline Podkarpackie & 108 & 34 & 33 & 16 & 25 & 39 & 25 & 25 & 19 \\
\hline Podlaskie & 78 & 23 & 29 & 18 & 8 & 23 & 14 & 26 & 15 \\
\hline Świętokrzyskie & 66 & 19 & 22 & 19 & 6 & 28 & 17 & 17 & 4 \\
\hline Warmińsko-mazurskie & 67 & 27 & 20 & 12 & 8 & 28 & 10 & 21 & 8 \\
\hline Number of units & 484 & 122 & 157 & 111 & 94 & 155 & 104 & 149 & 76 \\
\hline Average & 0.67 & 0.74 & 0.77 & 0.79 & 0.66 & 0.70 & 0.73 & 0.76 \\
\hline Range & \multicolumn{7}{|c|}{0.12} \\
\hline
\end{tabular}

Source: own development based on the data from the Local Data Bank of Statistics Poland and Central Statistical Office 

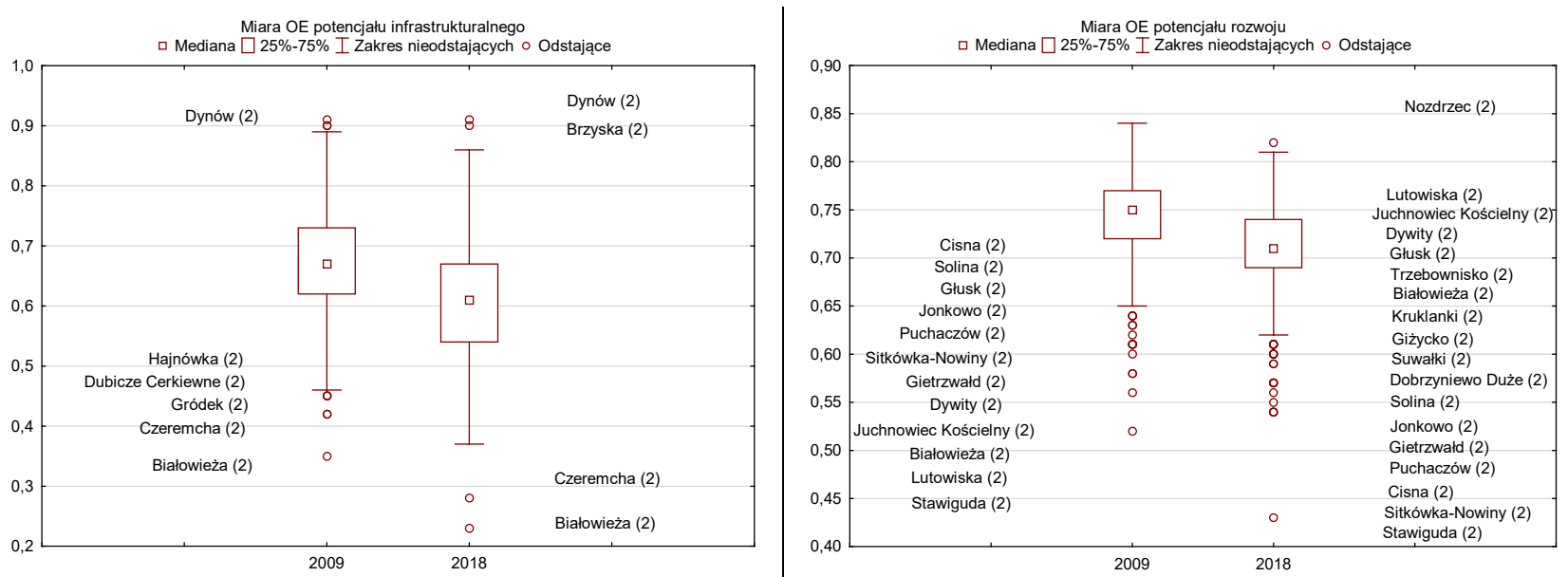

Figure 3. Dispersion of the measure of synthetic infrastructure and development of rural communes in Eastern Poland voivodeships in 2009 and 2018

(2) means of rural communes

Source: own development based on the data from the Local Data Bank of Statistics Poland and Central Statistical Office

Czeremcha, Białowieża - in terms of infrastructure; Nozdrzec, Lutowiska, Dywity, Głusk, Giżycko, Suwałki, Solina, Jankowo, Cisna, Sitkówka-Nowiny, and Stawiguda - in terms of development.

Analysis of the diversity of the measure of synthetic infrastructure indicates that in 2018, compared to 2009 , the degree of diversity of communes was higher. This is evidenced by the values of standard deviation (0.09-0.10), classic coefficient of variation (0.13-0.16) and range (0.56-0.68). Analysis of the development measure indicates the relative stability of diversity over the period under consideration, as evidenced by the standard deviation (0.04-0.04), the classic coefficient of variation (0.06-0.06) and the range (0.05-0.05; table 3 ).
Figure 4 presents correlograms describing the year-to-year relationship of measure of synthetic infrastructure and development. The correlation coefficient has been 0.552 (in 2018) and 0.589 (in 2009). This confirms a similar reaction of communes to changes in the economy and spatial stability of the studied phenomenon. Outliers were Kraśniczyn, Czeremcha, Białowieża, Dywity, Stawiguda (in 2018).

Analysis of Figure 5 shows that the best and weakest units in terms of development and infrastructure measures differ the least in terms of $\mathrm{OE}$ (e) entrepreneurship; OE (d) demography and labor market; OE (f) financial situation, and their greatest differentiation concerned OE (d) development; OE (i) infrastructure;

Table 3

Dispersion of the measure of synthetic infrastructure and development of rural communes in Eastern Poland voivodeships in 2009 and 2018

\begin{tabular}{|l|c|c|c|c|}
\hline \multirow{2}{*}{} & \multicolumn{2}{|c|}{ OE infrastructure } & \multicolumn{2}{c|}{ OE development } \\
\cline { 2 - 5 } & 2009 & 2018 & 2009 & 2018 \\
\hline average & 0.67 & 0.61 & 0.74 & 0.71 \\
\hline standard deviation & 0.67 & 0.61 & 0.75 & 0.71 \\
\hline quarter (quartile) deviation & 0.09 & 0.10 & 0.04 & 0.04 \\
\hline classic coefficient of variation & 0.68 & 0.61 & 0.75 & 0.72 \\
\hline positional coefficient of variation & 0.13 & 0.16 & 0.06 & 0.06 \\
\hline min & 1.01 & 0.99 & 0.99 & 0.01 \\
\hline max & 0.35 & 0.23 & 0.52 & 0.43 \\
\hline range & 0.91 & 0.91 & 0.84 & 0.82 \\
\hline quartile 1 & 0.56 & 0.68 & 0.72 & 0.69 \\
\hline quartile 2 & 0.62 & 0.54 & 0.75 & 0.71 \\
\hline quartile 3 & 0.67 & 0.61 & 0.77 & 0.74 \\
\hline quartile range & 0.73 & 0.67 & 0.05 & 0.05 \\
\hline skewness & 0.11 & 0.13 & -1.31 & -1.34 \\
\hline measure of concentration-kurtosis & -0.16 & -0.13 & 3.68 & 4.43 \\
\hline
\end{tabular}

Source: own development based on the data from the Local Data Bank of Statistics Poland and Central Statistical Office 

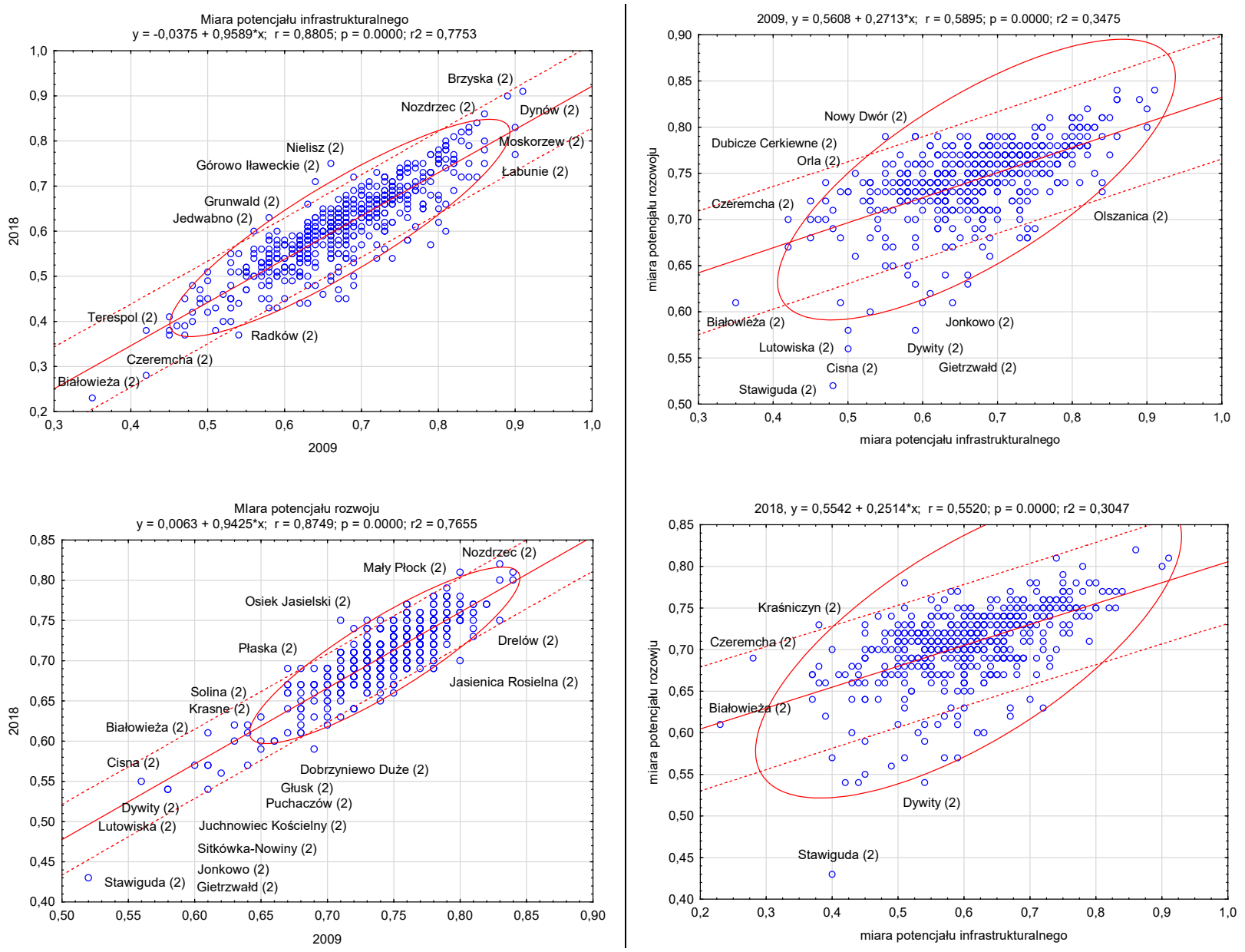

Figure 4. A scatter chart with a line matching the synthetic infrastructure measure and development of rural communes of Eastern Poland voivodeships in 2009 and 2018

Source: own development based on the data from the Local Data Bank of Statistics Poland and Central Statistical Office

Gunnar Myrdal in the theory of cumulative causation referring to the analysis of the interdependence of social, economic and institutional phenomena has proved that every element interacting with another element affects its behavior, and at the same time it is modified by the reaction of that element (Stanny, Strzelczyk, 2018). The level of infrastructure of rural municipalities in Poland was shaped primarily by the development process and financial situation (Table 4), but also by the number of people using libraries, sewage and water supply systems and housing resources (Table 5).

To assess the impact of endogenous potentials of communes on the spatial differentiation of infrastructure measures, a regression model describing the dependence of variables was estimated taking the form:

$\mathrm{F}$ (infrastructure measure $)=\sum(\mathrm{OE}(\mathrm{r})$ development; OE (p) entrepreneurship; OE (d) demography and labor market; OE (f) financial situation).

Table 4

Correlation between the measure of infrastructure and development of rural communes in Eastern Poland voivodeships in 2009 and 2018

\begin{tabular}{|l|c|c|}
\hline \multirow{2}{*}{ Synthetic measure of development } & 2009 & 2018 \\
\cline { 2 - 3 } & 0.5895 & 0.554 \\
\hline A synthetic measure of entrepreneurship & 0.0773 & 0.0204 \\
\hline A synthetic measure of demographic and the labor market & 0.024 & -0.0014 \\
\hline A synthetic measure of the financial situation & 0.1248 & 0.1593 \\
\hline
\end{tabular}

Linear correlation coefficients for observations from sample 1-484; Critical value (at a 5\% bilateral critical area) $=0.0891$ for $n=484$

Source: own development based on the data from the Local Data Bank of Statistics Poland and Central Statistical Office 

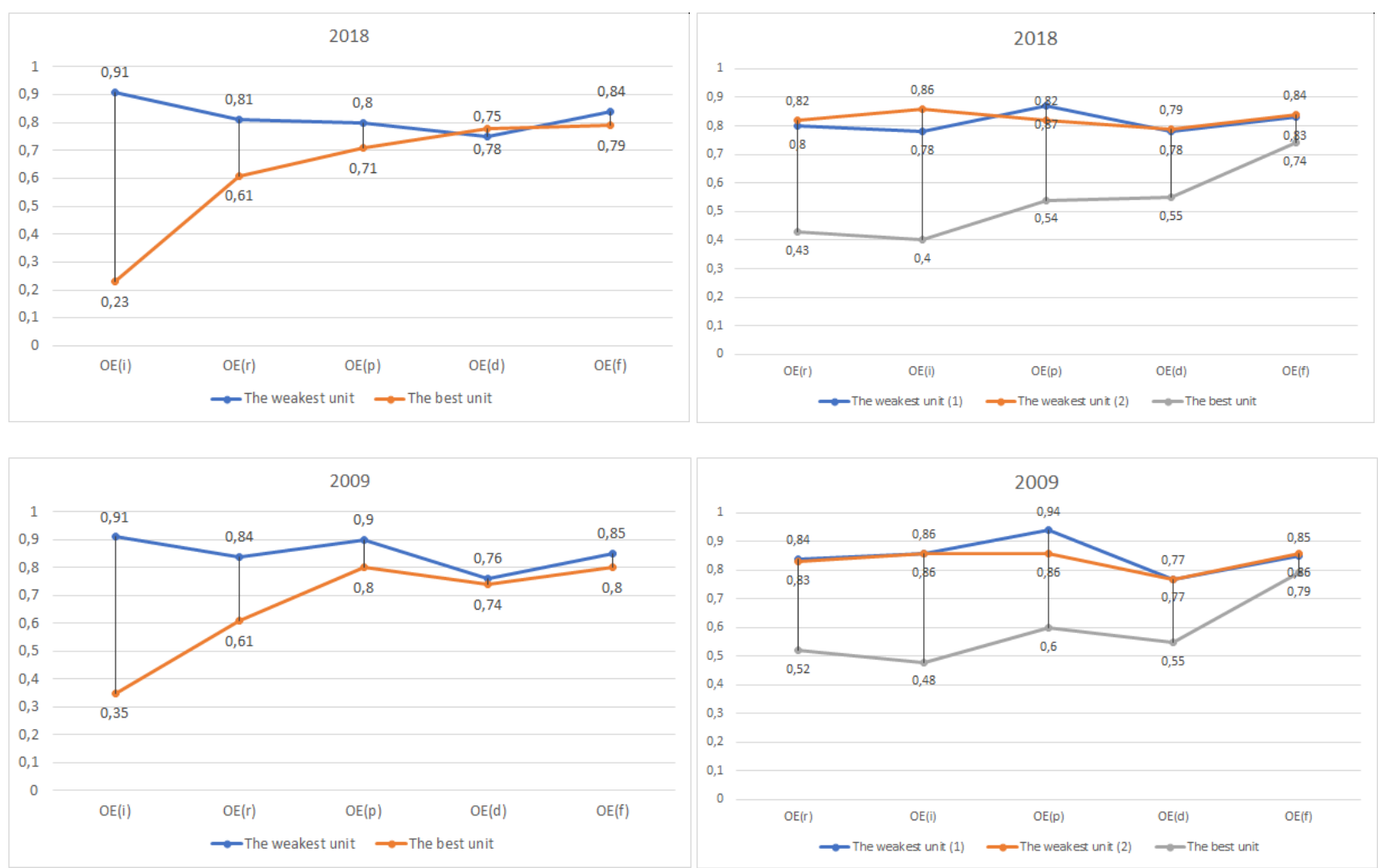

by infrastructure measure

by development measure

Figure 5. The weakest and best units by infrastructure and development measure of rural communes in Eastern Poland voivodeships in 2009 and 2018 $O E(d)$ development; $O E(i)$ infrastructure; $O E(e)$ entrepreneurship; $O E(d)$ demography and labor market; $O E(f)$ financial situation

Source: own development based on the data from the Local Data Bank of Statistics Poland and Central Statistical Office

Regression analysis of a measure of synthetic infrastructure versus endogenous potentials of municipalities that the presented regression model allows explaining $\mathrm{R}=0.809$ variable variations (at R2 = 0.807). The statistics values $\mathrm{F}(4.478)$ 507.4195 and the corresponding level of probability $\mathrm{p}$ mean that all parameters are statistically significant (Table 6).

Table 5

Correlation between the measure of infrastructure and elements describing it, rural communes of Eastern Poland voivodeships in 2009 and 2018

\begin{tabular}{|l|c|c|}
\hline \multirow{2}{*}{} & \multicolumn{2}{|c|}{ OE infrastructure } \\
\cline { 2 - 3 } & 2009 & 2018 \\
\hline Population per 1 library (person) & -0.5909 & -0.5672 \\
\hline Population using the sewage network & -0.526 & -0.4789 \\
\hline Population using the water supply system & -0.5139 & -0.4564 \\
\hline Housing stock & -0.4225 & -0.4286 \\
\hline
\end{tabular}

Linear correlation coefficients for observations from sample 1-484; Critical value (at a 5\% bilateral critical area) $=0.0891$ for $n=484$

Source: own development based on the data from the Local Data Bank of Statistics Poland and Central Statistical Office

\section{Conclusions}

Local development is a process of changes taking place in a given local system, taking into account the resources (territorial capital) appropriate for this system. Development is a general process, multidimensional process, covering economic, social, environmental, political and cultural aspects.

Regions with a high level of infrastructure development are areas recognized by investors and residents as attractive places for doing business and living. The level of infrastructure development in a given local system in terms of its structure, location, quality and accessibility has a very strong impact on its development.

The condition of the infrastructure (poor concentration in rural areas) in Eastern Poland is very diverse. The better the infrastructure is developed, the better and more attractive are the areas for the settlement and life of residents and the economic development of the region. The level of infrastructure determines development opportunities and barriers due to, among others, for their functions (location, integration, activation) or features (durability, relationship with the area, universality of access). 
Table 6

Model regression measure of synthetic infrastructure and socio-economic measures of rural communes in Eastern Poland voivodeships in 2018

\begin{tabular}{|c|c|c|c|c|}
\hline & Rate & standard error & t-Student's & p-Value \\
\hline const & 1.53566 & 0.0853103 & 18.00 & $<0.0001$ \\
\hline synthetic measure of development & 3.48871 & 0.0790483 & 44.13 & $<0.0001$ \\
\hline synthetic measure of entrepreneurship & -0.935703 & 0.0443394 & -21.10 & $<0.0001$ \\
\hline synthetic measure of demography & -1.65347 & 0.0769187 & -21.50 & $<0.0001$ \\
\hline synthetic measure of the financial situation & -1.74753 & 0.124013 & -14.09 & $<0.0001$ \\
\hline
\end{tabular}

\begin{tabular}{|l|c|l|c|}
\hline Arithmetic mean of the dependent variable & 0.606605 & Standard deviation of the dependent variable & 0.097853 \\
\hline Sum of residual squares & 0.879730 & Residual standard error & 0.042900 \\
\hline Determining coefficient R- square & 0.809385 & Corrected R-square & 0.807790 \\
\hline F $(4,478)$ & 507.4195 & P-value for the F test & $1,8 \mathrm{e}-170$ \\
\hline Logarithm of credibility & 838.0724 & Information criteria Akaike & $-1,666.145$ \\
\hline Bayesian, Schwarz information criterion & $-1,645.245$ & Hannan-Quinn criterion & $-1,657.932$ \\
\hline
\end{tabular}

KNK estimation, observations 1-484 used, Dependent variable ( $Y$ ): infrastructure 18

Source: own development based on the data from the Local Data Bank of Statistics Poland and Central Statistical Office

In 2018, the infrastructure measure ranged from 0.23 (best unit) to 0.91 (the weakest unit), and from 0.35 to 0.91 in 2009. In 2018, the measure of development ranged from 0.43 to 0.82 , while from 0.52 to 0.84 in 2009. This indicates a similar range of unit diversity and similar actions undertaken in the economy.

Regardless of the researched areas (infrastructure, development), Białowieża, Radków, Terespol, Łukta, Lutowiska, Rejowiec Fabryczny, Stawiguda, Juchnowiec Kościelny, Puchaczów and SitkówkaNowiny were high. A more favorable situation was in units with developed industrial functions (e.g. Sitkówka-Nowiny), which strengthened their investment financing possibilities and incurring liabilities from the operating surplus generated in these local governments. Units in the aspect of the measure of development and infrastructure differed the least in the aspect of entrepreneurship, demography and labor market as well as the financial situation, and the most in the aspect of infrastructure and development. The level of infrastructure of Eastern Polish rural communes was shaped primarily by the development process and financial situation but also by the number of people costing from libraries, sewage system and water supply as well as housing resources.

\section{References:}

Busłowska, A. (2011). Inwestycje w rozwój infrastruktury drogowej jako instrument polityki lokalnej gminy - ocena projektów realizowanych ze środków Unii Europejskiej w Mieście Biatystok, Zarządzanie Publiczne, 4(16).

Capello, R., \& Nijkamp, P. (2011). Regional growth and development revisited. In Endogenous Regional Development, Perspectives, Measurement and Empirical Investigation; Stimson R., Stough R., Nijkamp P., Eds.; Edward Elgar Publishing: Cheltenham, UK.

Dennis, L. (2004). Determinants of Financial Condition: A Study of US Cities. Orlando, FL: University of Central Florida.

Dolata, M. (2014). Infrastruktura gospodarcza jako czynnik kształtujący rozwój region, SERiA, Roczniki Naukowe, tom XV, zeszyt 3.

Douglas, J. W., \& Gaddie, R. K. (2002). State rainy day funds and fiscal crises: Rainy day funds and the 1990-1991 recession revisited, Public Budgeting \& Finance, t. 22. https://doi:10.1111/1540-5850.00063

Dworakowska, M. (2013). Zarzadzanie finansami miast na prawach powiatu, ZN US, nr 786 Finanse, Rynki Finansowe, Ubezpieczenia, nr 64/2.

Dziekański, P. (2016). Spatial Differentiation of the Financial Condition of the Świętokrzyskie Voivodeship Counties, Barometr Regionalny, tom 14, no. 3.

Dziekański, P. (2017). Diversification Synthetic Indicator For Evaluating The Financial Capacity Of Local Government. The Case Of Polish Voivodeships, Acta Universitatis Agriculturae Et Silviculturae Mendelianae Brunensis, vol. 65, no. 2. https://doi.org/10.11118/actaun201765020611

Dziekański, P., \& Wyszkowski, A. (2018). Ocena przestrzennego zróżnicowania sytuacji finansowej gmin województwa świętokrzyskiego z wykorzystaniem miary syntetycznej, Optimum. Economic Studies NR 1 (91) 2018.

Fierla, I. (1998). Struktura przestrzenna gospodarki, In: Geografia gospodarcza Polski, ed. I. Fierla, Wyd. Naukowe PWE, Warszawa. 
Gałązka, A. (2003). Infrastruktura komunalna na wsi. Początki, wspótczesność, perspektywy rozwoju, In: A. Stasiak (ed.), Problemy zagospodarowania terenów wiejskich w Polsce, PAN, KPZK, Biuletyn, z. 207, Warszawa.

Heffner, K. (2002). Czynniki osadnicze wptywajace na potencjat rozwojowy obszarów wiejskich, In: Wiejskie obszary kumulacji barier rozwojowych, Kłodziński M. (ed.), IRWiR PAN, Warszawa.

Heffner, K. (2002). Czynniki osadnicze wpływające na potencjał rozwojowy obszarów wiejskich, In: M. Kłodziński (ed.), Wiejskie obszary kumulacji barier rozwojowych, IRWiR PAN, Warszawa.

Infrastruktura techniczna a rozwój miasta, ed. D. Stawasz, Łódź 2005.

Jakubczyk, Z. (2002). Teoretyczne podstawy gospodarowania zasobami naturalnymi, In: Podstawy ekonomii środowiska zasobów naturalnych, ed. I. Fiedor, Wydawnictwo C.H. Beck, Warszawa, p. 120-125.

Karwińska, A. (2006). Działania na rzecz zmniejszania nierówności szans rozwojowych społeczności lokalnych w Polsce, Nierówności społeczne a wzrost gospodarczy, Uniwersytet Rzeszowski, Rzeszów.

Kolenda, M. (2003). Zamiana cechy na stymulantę, PN AE we Wrocławiu, Ekonometria, 11, nr 981, Zastosowania metod ilościowych.

Krajowy Raport o Rozwoju Społecznym, Polska 2012, Rozwój regionalny i lokalny, United Nations Development Programme, Warszawa.

Kuciński, K. (2009). Geografia ekonomiczna, Wyd. Oficyna a Wolters Kluwer Business, Kraków.

Kukuła, K. (2000). Metoda unitaryzacji zerowanej, PWN, Warszawa.

Malina, A. (2004). Wielowymiarowa analiza przestrzennego zróżnicowania struktury gospodarki Polski wedtug województw, Wyd. AE w Krakowie, Kraków.

Milczarek, T. (1999). Samorzad gminy: status prawny, organy, kompetencje, mienie, finanse, Wyd. PrawnoEkonomiczne INFOR, Warszawa.

Młodak, A. (2006). Analiza taksonomiczna w statystyce regionalnej, Centrum Doradztwa i Informacji Difin, Warszawa.

Nowak, E. (1990). Metody taksonomiczne w klasyfikacji obiektów spoteczno-gospodarczych, PWE, Warszawa.

Pięcek, B. (2002). Wpływ infrastruktury na rozwój przedsiębiorczości wiejskiej, In: Przedsiębiorczość wiejska w Polsce i krajach Unii Europejskiej, ed. M. Kłodziński, B. Fedyszak-Radziejowska, IRWiR PAN, Warszawa, p. 303-304.

Pięcek, B. (2002). Wplyw infrastruktury na rozwój przedsiębiorczości wiejskiej, In: M. Kłodziński, B. FedyszakRadziejowska (ed.), Przedsiębiorczość wiejska w Polsce i krajach Unii Europejskiej, IRWiR PAN, Warszawa.

Prus, P., \& Sadowski, A. (2012). Rozwój przedsiębiorczości na terenie gminy Tczew w województwie pomorskim jako efekt wstapienia Polski do Unii Europejskiej, Roczniki Naukowe SERiA, t. XIV, z. 2.

Rosner, A. (2000). Wiejskie obszary problemowe, synteza wyników czastkowych, In: Rosner A. (ed.), Lokalne bariery rozwoju obszarów wiejskich, Warszawa.

Rosner, A., \& Stanny, M. (2014). Monitoring rozwoju obszarów wiejskich. Etap I. Przestrzenne zróżnicowanie poziomu rozwoju społeczno-gospodarczego obszarów wiejskich w 2010 roku, IRWiR PAN, Warszawa.

Satoła, Ł., Standar, A., \& Kozera, A. (2019). Financial autonomy of local government units: Evidence from Polish rural municipalities, Lex Localis, 17(2).

Standar, A. (2017). Ocena kondycji finansowej gmin oraz jej wybranych uwarunkowań na przykładzie województwa wielkopolskiego przy wykorzystaniu metody TOPSIS, Wieś i Rolnictwo, 2 (175).

Stanny, M., \& Strzelczyk, W. (2018). Kondycja finansowa samorząów lokalnych a rozwój spoteczno-gospodarczy obszarów wiejskich; Ujęcie przestrzenne, Wydawca: Instytut Rozwoju Wsi i Rolnictwa PAN oraz Wydawnictwo Naukowe Scholar Spółka z o.o., Warszawa.

Sztando, A. (2013). Bariery zarządzania strategicznego rozwojem lokalnym zwiazane z cechami osobowymi lokalnych wtadz, In: Gospodarka lokalna w teorii i praktyce, ed. R. Brol, A. Sztando, Akademia Ekonomiczna we Wrocławiu, Wrocław.

Tokarski, T. 2005) Statystyczna analiza regionalnego zróżnicowania wydajności, zatrudnienia i bezrobocia w Polsce, Wydawnictwo PTE, Warszawa.

Waśniewsk, A. (2015). Wybrane społeczno-gospodarcze uwarunkowania rozwoju gmin w Polsce, Studia I Prace Wydziału Nauk Ekonomicznych i Zarządzania nr 40, t. 1. DOI: 10.18276/sip.2015.40/1-21

Wojtasiewicz, L. (1996). Ekonomiczne uwarunkowania rozwoju lokalnego, In: Rozwój lokalny i lokalna gospodarka przestrzenna, J.J. Parysek (ed.), Bogucki Wyd. Naukowe, Poznan.

Wojtyra, B. (2015). Wplyw renty położenia na lokalizację stref aktywności gospodarczej na obszarach wiejskich województwa wielkopolskiego, Rozwój Regionalny i Polityka Regionalna, 32.

Wysocki, F. (1996). Metody statystycznej analizy wielowymiarowej w rozpoznawaniu typów struktury przestrzennej rolnictwa, Roczniki AR w Poznaniu, seria: Rozprawy Naukowe, z. 266, Poznań.

Wysocki, F., \& Lira, J. (2005). Statystyka opisowa, Wyd. AR, Poznań. 